\title{
Antibacterial, Antitubercular and Antiviral Activity Evaluations of Some Arylidenehydrazide Derivatives Bearing Imidazo[2,1-b]thiazole Moiety
}

\author{
İmidazo[2,1-b]tiyazol Çekirdeği Taşıyan Bazı Arilidenhidrazit Türevlerinin \\ Antibakteriyel, Antitüberküler ve Antiviral Aktivite Tayinleri
}

\author{
Nuray ULUSOY GÜZELDEMIRCI ${ }^{*}$, Berin KARAMAN, Ömer KÜÇÜKBASMACl² \\ IIstanbul University, Faculty of Pharmacy, Department of Pharmaceutical Chemistry, İstanbul, Turkey \\ ${ }^{2}$ Istanbul University, Cerrahpaşa Faculty of Medicine, Department of Microbiology, İstanbul, Turkey
}

\begin{abstract}
Objectives: The aim of this study was to determine the probable antibacterial, antitubercular, and antiviral activities of some $N^{2}$-arylidene-(6-(4chlorophenyl)imidazo[2,1-b]thiazol-3-yl) acetic acid hydrazides (3a-j). Further structural optimization of the identified lead structures can lead us to new more active potential antibacterial, antitubercular, and antiviral agents.

Materials and Methods: Antibacterial activities of the title compounds against Staphylococcus aureus ATCC 29213, Pseudomonas aeruginosa ATCC 27853 and Escherichia coli ATCC 25922. These molecules were also evaluated for their in vitro antitubercular activity against Mycobacterium tuberculosis H37Rv (ATCC 27294) using the BACTEC 460 radiometric system and BACTEC 12B medium. Moreover, all the compounds (3a-j) were also evaluated against some DNA and RNA viruses in Madin-Darby Canine Kidney, Crandell-Rees Feline Kidney (CRFK), Vero, human embryonic lung (HEL) and HeLa cells.

Results: Among the tested compounds, 3i displayed the highest efficacy against S. aureus and E. coli. Compound 3j, 5-nitro-2-furfurylidene derivative showed the highest antituberculosis activity $\left(\mathrm{IC}_{50}: 6.16 \mu \mathrm{g} / \mathrm{mL}\right.$ and IC ${ }_{90}: 14.390 \mu \mathrm{g} / \mathrm{mL}$ ). Compound $3 \mathrm{i}$ showed the most potent antiviral activity against feline corona virus in CRFK cell cultures (antiviral $\mathrm{EC}_{50}: 7.5 \mu \mathrm{M}$ and $\mathrm{SI}>13$ ). Furthermore, compounds $3 \mathrm{c}$ and $3 \mathrm{~g}$ displayed activity against herpes simplex virus-1 and vaccinia virus in $\mathrm{HEL}$ cell cultures (antiviral $\mathrm{EC}_{50}$ values of 9; 16 and 20;14 $\mu \mathrm{M}$, respectively).

Conclusion: On the basis of aforementioned results, it can be conluded that imidazo[2,1-b]thiazole derivatives bearing hydrazone moieties serve as promising chemical probes to design therapeutic agents with antibacterial, antitubercular, and antiviral properties.
\end{abstract}

Key words: Imidazo[2,1-b]thiazole, arylidenehydrazide, antibacterial activity, antitubercular activity, antiviral activity

Öz

Amaç: Bu çalışmanın amacı, bazı $N^{2}$-ariliden-(6-(4-klorofenil)imidazo[2,1-b]tiyazol-3-il) asetik asit hidrazitlerinin (3a-j) olası antibakteriyel, antitüberküler ve antiviral aktivitelerinin tayin edilmesidir. Tanımlanmış yapıların ileri yapısal optimizasyonu, bizi daha aktif potansiyel antibakteriyel, antitüberküler ve antiviral ajanlara ulaştırabilir.

Gereç ve Yöntemler: Söz konusu bileșiklerin antibakteriyel aktiviteleri, Staphylococcus aureus ATCC 29213, Pseudomonas aeruginosa ATCC 27853 ve Escherichia coli ATCC 25922'ye karşı tayin edilmiștir. Bu moleküllerin, Mycobacterium tuberculosis H37Rv (ATCC 27294) karşı in vitro antitüberküler aktiviteleri de BACTEC 460 radiometrik sistem ve BACTEC 12B ortamı kullanılarak tayin edilmiștir. Dahası, bileșiklerin tümü (3a-j), Madin-Darby Canine Kidney, Crandell-Rees Feline Kidney (CRFK), Vero, insan embriyonik akciğeri (HEL) ve HeLa hücrelerinde bazı DNA ve RNA virüslerine karşı tayin edilmiștir.

*Correspondence: E-mail: nulusoy@istanbul.edu.tr, Phone: +90 5325749263

ORCID ID: orcid.org/0000-0002-4495-4282

Received: 16.08.2016, Accepted: 23.10.2016

๑Turk J Pharm Sci, Published by Galenos Publishing House. 
Bulgular: Test bileşikleri arasında, 3i, S. aureus ve E. coli'ye karşı en yüksek etkinliği göstermiştir. 5-Nitro-2-furfuriliden türevi 3j bileșiği, en yüksek antitüberküler aktivite göstermiştir ( $I_{50}: 6.16 \mu \mathrm{g} / \mathrm{mL}$ ve $I_{90}: 14.390 \mu \mathrm{g} / \mathrm{mL}$ ). Bileşik 3i, en güçlü antiviral aktiviteyi CRFK hücre kültürlerinde feline corona virüse karşı göstermiştir (antiviral $\mathrm{EC}_{50}: 7.5 \mu \mathrm{M}$ ve SI>13). Ayrıca, $3 \mathrm{c}$ ve $3 \mathrm{~g}$ bileşikleri HEL hücre kültürlerinde, herpes simpleks virüs-1 ve aşı virüsüne karşı aktivite göstermişlerdir (antiviral $\mathrm{EC}_{50}$ değerleri sırasıyla 9; 16 ve 20; $14 \mu \mathrm{M}$ 'dir).

Sonuç: Yukarıda sözü edilen sonuçlara dayanarak, hidrazon çekirdeği taşıyan imidazo[2,1-b]tiyazol türevleri, antibakteriyel, antitüberküler ve antiviral özelliklere sahip terapötik ajanlar tasarlamak için umut verici kimyasal problar olarak yarar sağlayabilir.

Anahtar kelimeler: İmidazo[2,1-b]tiyazol, arilidenhidrazid, antibakteriyel aktivite, antitüberküler aktivite, antiviral aktivite

\section{INTRODUCTION}

Infectious diseases caused by bacteria have increased dramatically in recent years. Despite many significant advances in antibacterial therapy, the widespread use and misuse of antibiotics have led to the emergence of bacterial resistance to antibiotics, which is a serious threat to public health. On the other hand, tuberculosis (TB), still remains the leading cause of worldwide death among infectious diseases., ${ }^{1,2}$ In 2014, there were an estimated 9.6 million new TB cases: 5.4 million among men, 3.2 million among women and 1.0 million among children. ${ }^{3}$ Additionally, viral infections caused by the rapid emergence of antiviral drug resistant strains have become a serious threat globally. ${ }^{4}$ Many diseases are actually caused by the different members of DNA- and RNA-containing viruses. Among DNAcontaining viruses, the herpes group of viruses, particularly herpes simplex virus-1 (HSV-1) primarily causes encephalitis, stomatitis, ocular infections and HSV-2 primarily causes genital lesions, skin eruptions or cytomegalovirus is related with severe morbidity and mortality in patients at risk for disease because of immune system disabilities and varicella-zoster virus is the ethiological agent of chickenpox and shingles. 5,6 Influenza (INF) viruses, parainfluenza-3 virus, alphaviruses (e.g. sindbis virus), respiratory syncytial virus (RSV) and vesicular stomatitis virus (VSV) are examples of enveloped single-stranded RNAcontaining viruses. VSV causes an economically important disease in horses and cattle. ${ }^{7}$ Both RSV and parainfluenza-3 virus are an important cause of respiratory tract infections. ${ }^{8,9}$

Among the heterocyclic rings containing bridgehead nitrogen atom, imidazo[2,1-b]thiazoles derivatives are especially attractive because of their different biological activities such us antibacterial, ${ }^{10}$ antituberculosis, ${ }^{11}$ antiviral, ${ }^{12}$ anticancer, ${ }^{13}$ antiinflammatory ${ }^{14}$ and diuretic ${ }^{15}$ activities. On the other hand, arylidenehydrazide moiety are also associated with various biological properties including antibacterial, ${ }^{16}$ antitubercular, ${ }^{17}$ antiviral, $^{18}$ anticancer, $^{19}$ antiinflammatory and analgesic ${ }^{20}$ activities.

In continuation of our previous studies on the biological properties of imidazo[2,1-b]thiazole derivatives, ${ }^{21-27}$ in this study, we reported the antibacterial, antitubercular and antiviral activity evaluation of some arylidenehydrazide derivatives bearing imidazo[2,1-b]thiazole moiety.

\section{MATERIALS AND METHODS}

\section{Chemistry}

All chemicals were purchased from Merck (Darmstadt, Germany) or Sigma-Aldrich (St. Louis, MO, USA) chemical companies. Using a Büchi B-540 melting point apparatus (Flawil, Switzerland) with open capillaries, melting points were determined and are uncorrected. Elemental analyses were performed on a Thermo Finnigan Flash EA 1112 elemental analyser. Infrared spectra were recorded (in $\mathrm{KBr}$ ) using a Perkin Elmer Spectrum 100 fourier transform infrared (FTIR) spectrometer and Shimadzu IRAffinity-1 FTIR spectrophotometer. ${ }^{1} \mathrm{H}$ and ${ }^{13} \mathrm{C}$-nuclear magnetic resonance spectra were obtained on Varian UNITY INOVA $500 \mathrm{MHz}$ spectrometer using dimetil sulfoxide- $\mathrm{d}_{6}$ as an internal standard. All chemical shifts were reported as $\delta$ (ppm) values and spin-spin couplings $(\mathrm{J})$ were exposed in $\mathrm{Hz}$. MS (ESI-) were determined on a Finnigan LCQ Advantage Max mass spectrometer.

General synthesis of $N^{2}$-arylidene-(6-(4-chlorophenyl) imidazo[2,1-b]thiazol-3-yl)acetic acid hydrazides (3a-3j) $)^{28}$

A solution of $0.005 \mathrm{~mol}$ compound 2 and $0.005 \mathrm{moL}$ of an appropriate aromatic aldehyde in $100 \mathrm{~mL}$ ethanol was heated under reflux for $5 \mathrm{~h}$. The precipitate obtained was purified either by recrystallization from ethanol or by washing with hot ethanol.

\section{Biological activity}

\section{Antibacterial activity}

Minimum inhibitory concentrations (MICs) were determined by the microbroth dilution method using the National Committee for Clinical Laboratory Standards recommendations. ${ }^{29}$ MuellerHinton broth (Oxoid, Hemakim, Turkey) was used as the test medium. An inoculum of approximately $5 \times 10^{5} \mathrm{CFU} \mathrm{\textrm {cm } ^ { - 3 }}$ was delivered per well. Serial twofold dilutions of the test compounds (128-0.25 $\mathrm{\mu g} / \mathrm{mL}$ ) and extra dilutions (256-0.25 $\mu \mathrm{g} / \mathrm{mL}$ ) for antibiotic standards were prepared. Plates were incubated for $16-20 \mathrm{~h}$ at $35^{\circ} \mathrm{C}$ in an ambient air incubator. The lowest concentration of the test compounds inhibiting visible growth was taken as the MIC value.

\section{Antitubercular activity}

In vitro evaluation of antitubercular activity

Primary screening was conducted at $6.25 \mathrm{mg} / \mathrm{mL}$ against Mycobacterium tuberculosis $\mathrm{H}_{37} \mathrm{Rv}$ in BACTEC 12B medium using a broth microdilution assay the Microplate Alamar Blue Assay (MABA). ${ }^{30}$ Compounds exhibiting fluorescence were tested in the BACTEC 460 radiometric system. ${ }^{31}$ Compounds effecting $<90 \%$ inhibition in the primary screen were not generally evaluated further. Compounds demonstrating at least $90 \%$ inhibition in the primary screen were re-tested at lower concentrations against $M$. tuberculosis $\mathrm{H}_{37} \mathrm{Rv}$ in order 
to determine the actual MIC using MABA. The MIC was defined as the lowest concentration effecting a reduction in fluorescence of $90 \%$ relative to the controls. Concurrently with the determination of MICs, compounds were tested for cytotoxicity $\left(\mathrm{IC}_{50}\right)$ in VERO cells at concentrations $£ 6.25 \mathrm{mg} / \mathrm{mL}$ or 10 times the MIC for M. tuberculosis $\mathrm{H}_{37} \mathrm{Rv}$ (solubility in media permitting). After $72 \mathrm{~h}$ exposure, viability was assessed on the basis of cellular conversion of 3-(4,5-dimethylthiazol-2-yl)-2,5diphenyl tetrazolium bromide into a formazan product using the Promega CellTiter 96 Non-radioactive Cell Proliferation Assay. Compounds for which the selectivity index (IC ${ }_{50}$ : MIC ratio) $\mathrm{SI}>10$ were assumed to possess in vitro activity confirmed in the BACTEC 460 at $6.25 \mathrm{mg} / \mathrm{mL}$.

\section{Microplate alamar blue susceptibility assay}

Antimicrobial susceptibility testing was performed in black, clear-bottomed, 96-well microplates (black view plates; Packard Instrument, Meriden, Connecticut, USA) in order to minimize background fluorescence. Outer perimeter wells were filled with sterile water to prevent dehydration in experimental wells. Initial drug dilutions were prepared in either dimethyl sulfoxide or distilled deionized water, and subsequent twofold dilutions were performed in $0.1 \mathrm{~mL}$ of $7 \mathrm{H} 9 \mathrm{GC}$ (no Tween 80) in the microplates. BACTEC 12B-passaged inocula were initially diluted $1: 2$ in $7 \mathrm{H} 9 \mathrm{GC}$, and $0.1 \mathrm{~mL}$ was added to wells. Subsequent determination of bacterial titers yield $1 \times 10^{6} \mathrm{CFU} /$ $\mathrm{mL}$ in plate wells for $\mathrm{H}_{37} \mathrm{Rv}$. Frozen inocula were initially diluted $1: 20$ in BACTEC 12B medium followed by a 1:50 dilution in $7 \mathrm{H} 9 \mathrm{GC}$. Addition of $1 / 10 \mathrm{~mL}$ to wells resulted in a final bacterial titers of $2.0 \times 10^{5} \mathrm{CFU} / \mathrm{mL}$ for $\mathrm{H}_{37} \mathrm{Rv}$. Wells containing drug only were used to detect autofluorescence of compounds. Addition control wells consisted of bacteria only (B) and medium only $(\mathrm{M})$. Plates were incubated at $37^{\circ} \mathrm{C}$. Starting at day 4 of incubation, $20 \mathrm{~mL}$ of $10 x$ Alamar Blue solution (Alamar Biosciences/Accumed, Westlake, Ohio, USA) and $12.5 \mathrm{~mL}$ of $20 \%$ Tween 80 were added to one B well an done $M$ well, and plates were reincubated $37^{\circ} \mathrm{C}$. Wells were observed at 12 and $24 \mathrm{~h}$ for a color change from blue to pink and for a reading of $\geq 50.000$ fluorescence units (FU). Fluorescence was measured in a Cytofluor II microplate fluorometer (Perseptive Biosystems, Framingham, Massachusetts, USA) in bottom-reading mode with excitation at $530 \mathrm{~nm}$ and emission at $590 \mathrm{~nm}$. If the B wells became pink by $24 \mathrm{~h}$, reagent was added to the entire plate. If the well remained blue or $£ 50.000 \mathrm{FU}$ was measured, additional M and $B$ wells were tested daily until a color change occurred, at which time reagents were added to all remaining wells. Plates were then incubated at $37^{\circ} \mathrm{C}$, and results were recorded at $24 \mathrm{~h}$ post-reagent addition. Visual MICs were defined as the lowest concentration of drug that had prevented a color change. For fluorometric MICs, a background subtraction was performed on all wells with a mean of triplicate $M$ wells. Percent inhibition was defined as 1-(test well FU/mean FU triplicate B wells) $x$ 100. The lowest drug concentration effecting an inhibition of $\geq 90 \%$ was considered the MIC.

\section{BACTEC radiometric method of susceptibility testing}

Inocula for susceptibility testing were either from a positive BACTEC isolation vial with a growth index (GI) of 500 or more, or a suspension of organisms isolated earlier on a conventional medium. The culture was well mixed with a syringe and $0.1 \mathrm{~mL}$ of a positive BACTEC culture was added to each of the vials containing the test compounds $(6.25 \mathrm{mg} / \mathrm{mL})$. The standard vials contained rifampicin $(0.25 \mathrm{mg} / \mathrm{mL})$. A control vial was inoculated with a 1:100 dilution of the culture. Each vial was tested immediately on a BACTEC instrument to provide $\mathrm{CO}_{2}$ in the headspace. The vials were incubated at $37^{\circ} \mathrm{C}$ and tested daily with a BACTEC instrument. When the $\mathrm{Gl}$ in the control read at least 30 , the increase in $\mathrm{Gl}(\Delta \mathrm{GI})$ from the previous day in the control was compared with that in the drug vial. The following formula was used to interpret the results:

$\Delta \mathrm{Gl}$ control $>\Delta \mathrm{Gl}$ drug $=$ susceptible

$\Delta \mathrm{Gl}$ control $<\Delta \mathrm{Gl}$ drug $=$ resistant

If a clear susceptibility pattern (the difference of $\Delta \mathrm{Gl}$ of control and the drug bottle) was not seen at the time the control GI was 30 the vials were read for 1 or 2 additional days to establish a definite pattern of $\Delta \mathrm{Gl}$ differences.

\section{Antiviral activity}

The compounds (3a-j) were evaluated for activity against diverse RNA- and DNA-viruses, using the following cell-based assays $^{32}$ : (a) Madin-Darby Canine Kidney (MDCK) cells infected with INF A/H1N1 subtype (A/Ned/378/05), INF A/H3N2 subtype (A/HK/7/87) or INF B (B/Ned/537/05); (b) Crandell-Rees Feline Kidney (CRFK) cells infected with feline corona virus (FCoV) or feline herpes virus (FHV); (c) African green monkey kidney Vero cells infected with parainfluenza-3 virus, reovirus-1, Sindbis virus, Coxsackie B4 virus or Punta toro virus; (d) human embryonic lung (HEL) fibroblast cells infected with HSV-1 or -2, an acyclovir-resistant HSV-1 strain, vaccinia virus, VSV; (e) human cervixcarcinoma Henrietta Lacks (HeLa) cells infected with VSV, coxsackie B4 virus or RSV.

To perform the antiviral assays, the virus was added to subconfluent cell cultures in 96-well plates, and at the same time, the test compounds were added at serial dilutions. Appropriate reference compounds were included, i.e. the virus entry inhibitor dextran sulfate 5000, the broad antiviral agent ribavirin, the antiherpetic drug ganciclovir, and the HIV inhibitor azidothymidine. After 3-6 days incubation at $37^{\circ} \mathrm{C}$ (or $35^{\circ} \mathrm{C}$ in the case of INF virus), the cultures were examined by microscopy to score the compounds' inhibitory effect on virus-induced cytopathic effect or their cytotoxicity. For some viruses, antiviral and cytotoxic activities were confirmed by the colorimetric 3-(4,5-carboxymethoxyphenyl)-2-(4-sulfophenyl)$2 \mathrm{H}$-tetrazolium cell viability assay.

\section{RESULTS AND DISCUSSION}

The key intermediate 2 was prepared from ethyl (6-(4-chlorophenyl)imidazo[2,1-b]thiazol-3-yl)acetate hydrobromide (1) and hydrazine hydrate following the literature method. ${ }^{33}$ The synthetic route of the compounds is outlined in Scheme 1. Condensation of 2 with appropriate aromatic aldehyde afforded the corresponding $N^{2}$-arylidene-(6-(4- 
chlorophenyl)imidazo[2,1-b]thiazol-3-yl)acetic acid hydrazides $(3 a-j) .^{28}$

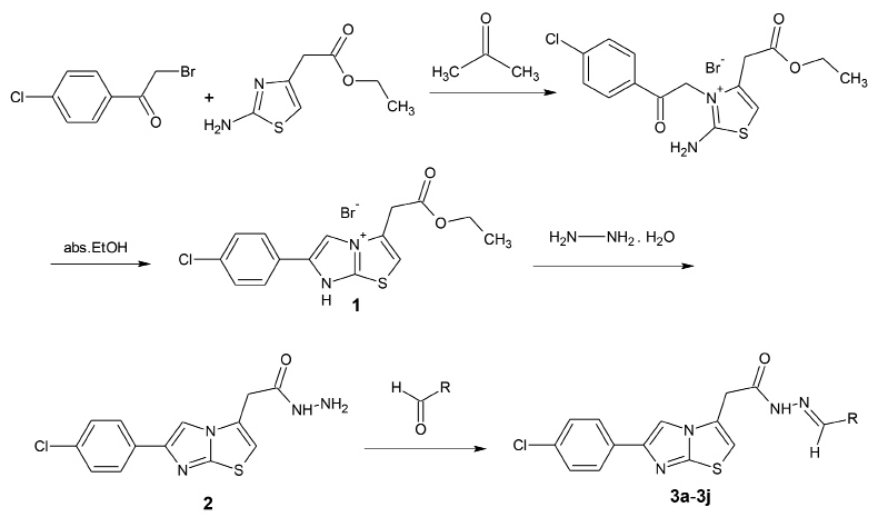

Scheme 1. Synthesis of the title compounds $(3 a-j)$

Compounds 3a-j were evaluated for in vitro antibacterial activity against Staphylococcus aureus ATCC 29213, Pseudomonas aeruginosa ATCC 27853 and Escherichia coli ATCC 25922 using the microbroth dilution method ${ }^{29}$. As can be seen in Table 1, $3 \mathrm{i}$ (2,4-dichlorobenzylidene derivative) showed the highest activity against S. aureus ATCC 29213 and E. coli ATCC 25922 (MIC: $2 \mu \mathrm{g} / \mathrm{mL}, 64 \mu \mathrm{g} / \mathrm{mL}$, respectively).

Compounds 3a-j were evaluated against M. tuberculosis $\mathrm{H}_{37} \mathrm{Rv}$ (ATCC 27294) in BACTEC 12B medium using a broth microdilution assay, the MABA. The primary antituberculosis screening was performed in accordance with the protocol of the Tuberculosis Antimicrobial Acquisition and Coordinating Facility Southern Research Institute ${ }^{30}$. Rifampin was used as the control drug in the tests. Compounds demonstrating a percent inhibition of bacterial growth of greater than or equal to $90 \%$ in the primary screen were retested against $M$. tuberculosis $\mathrm{H}_{37} \mathrm{Rv}$, to determine the actual MIC in the MABA. The MIC was defined as the lowest concentration effecting a reduction in fluorescence of $90 \%$, relative to controls. This value was determined from the doseresponse curve as the $\mathrm{IC}_{90}$ using a curve fitting program. Any $\mathrm{IC}_{90}$ value of $\leq 10 \mu \mathrm{g} / \mathrm{mL}$ was considered "Active" for antitubercular activity. Compounds active in the initial screen were tested for $\mathrm{IC}_{50}$ in Vero cells. Cytotoxicity was determined from the dose-response curve as the $\mathrm{IC}_{50}$ using a curve fitting program. Concurrent with the determination of MICs, compounds were tested for cytotoxicity in Vero cells at concentrations 10x the MIC for M. tuberculosis $\mathrm{H}_{37}$ Rv. Most of the tested compounds showed weakly antitubercular activity and cytotoxicities of the compounds were found to be very high (Table 2).

The compounds (3a-j) were also evaluated against INF $A$ / H1N1 subtype (A/Ned/378/05), INF A/H3N2 subtype (A/ $\mathrm{HK} / 7 / 87)$, INF B (B/Ned/537/05) in MDCK, FCoV, FHV in CRFK, parainfluenza-3 virus, reovirus-1, sindbis virus, coxsackie B4 virus, punta toro virus in Vero, HSV-1 (KOS), HSV-2 (G), HSV-1
TK KOS ACV, vaccinia virus, VSV, in HEL and VSV, coxsackie B4 virus and RSV in HeLa cell cultures. As can be seen in Table 3, the most active compound was $\mathrm{R}=2,4$-dichlorophenyl substituted $3 \mathrm{i}$. It inhibited FCoV with $E C_{50}$ of $7.5 \mu \mathrm{M}$. R=4hydroxyphenyl substituted derivative 3c, inhibited HSV-1 (KOS), HSV-2 (G), HSV-1 TK KOS ACV, vaccinia virüs and VSV with $E C_{50}$ of $9,27,32,16$ and $32 \mu \mathrm{M}$, respectively. $\mathrm{R}=3$-methoxy-4hydroxyphenyl substituted $3 \mathrm{~g}$ showed $\mathrm{EC}_{50}$ values of 20 and $14 \mu \mathrm{M}$ for HSV-1 (KOS) and $\mathrm{v}$ virus, respectively (Table 4). However, tested compounds (3a-j) didn't show any inhibition against INF $A / H 1 N 1$ subtype (A/Ned/378/05), INF $A / H 3 N 2$ subtype (A/HK/7/87), INF B (B/Ned/537/05), parainfluenza-3

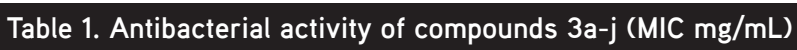

\begin{tabular}{|c|c|c|c|c|}
\hline $\begin{array}{l}\text { Comp./ } \\
{ }^{*} \text { microorg. }\end{array}$ & $\mathrm{R}$ & A & B & C \\
\hline $3 a$ & $\mathrm{C} 6 \mathrm{H} 5$ & 128 & $>128$ & 128 \\
\hline $3 b$ & $\mathrm{C}_{6} \mathrm{H}_{4}(\mathrm{OH})(2-)$ & $>128$ & $>128$ & $>128$ \\
\hline $3 c$ & $\mathrm{C}_{6} \mathrm{H}_{4}(\mathrm{OH})(4-)$ & 128 & 128 & $>128$ \\
\hline $3 d$ & $\mathrm{C}_{6} \mathrm{H}_{4}(\mathrm{OCH} 3)(4-)$ & 64 & 128 & 128 \\
\hline $3 e$ & $\mathrm{C}_{6} \mathrm{H}_{4}\left(\mathrm{NO}_{2}\right)(4-)$ & $>128$ & $>128$ & $>128$ \\
\hline $3 f$ & $\mathrm{C}_{6} \mathrm{H}_{4}\left(\mathrm{~N}\left(\mathrm{CH}_{3}\right)_{2}\right)(4-)$ & 128 & $>128$ & 128 \\
\hline $3 g$ & $\mathrm{C}_{6} \mathrm{H}_{3}\left(\mathrm{OCH}_{3}\right)(\mathrm{OH})(3,4-)$ & 128 & $>128$ & $>128$ \\
\hline $3 \mathrm{~h}$ & $\mathrm{C}_{6} \mathrm{H}\left(\mathrm{OCH}_{3}\right)_{2}(2,5-)$ & $>128$ & $>128$ & 128 \\
\hline $3 i$ & $\mathrm{C}_{6} \mathrm{H}\left(\mathrm{Cl}_{2}\right)(2,4-)$ & 32 & $>128$ & 64 \\
\hline $3 j$ & 5-nitro-2-furyl & 128 & 128 & 128 \\
\hline Amikacin & - & 1 & 1 & 2 \\
\hline
\end{tabular}

MIC: Minimum inhibitory concentrations, *A: Staphylococcus aureus ATCC 29213, B: Pseudomonas aeruginosa ATCC 27853, C: Escherichia coli ATCC 25922

Table 2. Antimycobacterial activity screening results of $3 a-j$ (MIC $\mathrm{mg} / \mathrm{mL}$ )

\begin{tabular}{lllll} 
Compound & Assay & $\mathrm{IC}_{50}(\mathrm{mg} / \mathrm{mL})$ & $\mathrm{IC}_{90}(\mathrm{mg} / \mathrm{mL})$ & Activity \\
\hline 3a & n.t. & n.t. & n.t. & n.t. \\
\hline 3b & MABA & $>100$ & $>100$ & Inactive \\
\hline 3c & MABA & 22.710 & 33.060 & Weakly active \\
\hline 3d & MABA & 69.170 & $>100$ & Weakly active \\
\hline 3e & MABA & $>100$ & $>100$ & Inactive \\
\hline 3f & MABA & $>100$ & $>100$ & Weakly active \\
\hline 3g & MABA & 20.670 & 36.860 & Weakly active \\
\hline 3h & MABA & 44.720 & $>100$ & Weakly active \\
\hline 3i & MABA & $>100$ & $>100$ & Inactive \\
\hline 3j & MABA & 6.16 & 14.390 & Weakly active \\
\hline Rifampicin & & & 0.125 & \\
\hline
\end{tabular}

MIC: Minimum inhibitory concentrations, MABA: Microplate Alamar Blue Assay, n.t.: not tested 
virus, reovirus-1, sindbis virus, coxsackie B4 virus, punta toro virüs, VSV, coxsackie B4 virus and RSV strains (i.e. minimal antivirally effective concentration $\geq 5$-fold lower than minimal cytotoxic concentration) (Table 5).

\section{CONCLUSION}

In this work, a series of arylidenehydrazide derivatives bearing imidazo[2,1-b]thiazole moiety was evaluated for antibacterial, antitubercular and antiviral activities. The results showed that some compounds exhibited antibacterial, antimycobacterial and antiviral activities with different percentage of inhibition. Therefore, we have identified a novel series of imidazo[2,1-b] thiazoles, which may develop into the potential class of antibacterial, anti-tubercular and antiviral agents.

\section{ACKNOWLEDGEMENTS}

We thank Prof. Lieve Naesens from the Rega Institute for Medical Research, Katholieke Universiteit Leuven, B-3000 Leuven, Belgium for evalution of antiviral activity. We thank Dr. Joseph A. Maddry from the Tuberculosis Antimicrobial Acquisition and Coordinating Facility (TAACF), National Institute of Allergy and Infectious Diseases Southern Research Institute, Alabama, USA, for the evaluation of anti-TB activity. The present work was supported by İstanbul University Scientific Research Projects (Project No: 49399).
Table 3. Anti-feline corona virus and anti-feline herpes virus activity and cytotoxicity of the compounds $3 a-j$ in Crandell-Rees Feline Kidney cell cultures

\begin{tabular}{llll} 
Compound & $\mathrm{CC}_{50}{ }^{\mathrm{a}}(\mu \mathrm{M})$ & $\mathrm{EC}_{50}{ }^{\mathrm{b}}(\mu \mathrm{M})$ & \\
\cline { 2 - 4 } $3 \mathrm{FC}$ & $>100$ & $>100$ & $>100$ \\
\hline $3 \mathrm{~b}$ & 50.6 & $>20$ & $>20$ \\
\hline $3 \mathrm{c}$ & 20.7 & $>20$ & $>20$ \\
\hline $3 \mathrm{~d}$ & $>100$ & $>100$ & $>100$ \\
\hline $3 \mathrm{e}$ & 4.4 & $>4$ & $>4$ \\
\hline $3 \mathrm{f}$ & 50.8 & $>20$ & $>20$ \\
\hline $3 \mathrm{~g}$ & 24.5 & $>20$ & $>20$ \\
\hline $3 \mathrm{~h}$ & $>100$ & $>100$ & $>100$ \\
\hline $3 \mathrm{i}$ & $>100$ & 7.5 & 54.8 \\
\hline $3 \mathrm{j}$ & 9.7 & $>4$ & $>4$ \\
\hline $\mathrm{HHA}(\mu \mathrm{g} / \mathrm{mL})$ & $>100$ & 5.3 & 8.8 \\
\hline UDA $(\mu \mathrm{g} / \mathrm{mL})$ & $>100$ & 17.7 & 12.9 \\
\hline Ganciclovir $(\mu \mathrm{M})$ & $>100$ & $>100$ & 3.6 \\
\hline
\end{tabular}

FCoV: Feline corona virüs, FHV: Feline herpes virüs, HHA: Hippeastrum hybrid agglutinin, UDA: Urtica dioica agglutinin, MTS: 3-(4,5-dimethylthiazol-2-yl)5(3-carboxymethonyphenol)-2-(4-sulfophenyl)-2H-Tetrazolium, ${ }^{a 50 \%}$ cytotoxic concentration, as determined by measuring the cell viability with the colorimetric, formazan-based MTS assay, ${ }^{b} 50 \%$ effective concentration, or concentration producing $50 \%$ inhibition of virus-induced, cytopathic effect, as determined by measuring e cell viability with the colorimetricformazan-based MTS assay

Table 4. Antiviral activity and cytotoxicity of the compounds 3a-j in human embryonic lung cell cultures

\begin{tabular}{|c|c|c|c|c|c|c|}
\hline \multirow{2}{*}{ Compound } & \multirow{2}{*}{$\begin{array}{l}\mathrm{MCC}^{\mathrm{a}} \\
(\mu \mathrm{M})\end{array}$} & \multicolumn{5}{|c|}{$\mathrm{EC}_{50}{ }^{\mathrm{b}}(\mu \mathrm{M})$} \\
\hline & & $\begin{array}{l}\text { Herpes simplex virus-1 } \\
\text { (KOS) }\end{array}$ & $\begin{array}{l}\text { Herpes simplex } \\
\text { virus-2 (G) }\end{array}$ & $\begin{array}{l}\text { Herpes simplex virus-1 } \\
\text { TK KOS ACV }\end{array}$ & Vaccinia virus & $\begin{array}{l}\text { Vesicular stomatitis } \\
\text { virus }\end{array}$ \\
\hline $3 a$ & $>100$ & $>100$ & $>100$ & $>100$ & $>100$ & $>100$ \\
\hline $3 b$ & $>100$ & $>100$ & $>100$ & $>100$ & $>100$ & $>100$ \\
\hline $3 c$ & $\geq 100$ & 9 & 27 & 32 & 16 & 32 \\
\hline $3 d$ & 100 & $>20$ & $>20$ & $>20$ & $>20$ & $>20$ \\
\hline $3 e$ & $>100$ & $>100$ & $>100$ & $>100$ & $>100$ & $>100$ \\
\hline $3 f$ & $>100$ & $>100$ & $>100$ & $>100$ & $>100$ & $>100$ \\
\hline $3 g$ & 500 & 20 & $>100$ & $>100$ & 14 & $>100$ \\
\hline $3 \mathrm{~h}$ & 100 & $>20$ & $>20$ & $>20$ & $>20$ & $>20$ \\
\hline $3 i$ & 100 & $>20$ & $>20$ & $>20$ & $>20$ & $>20$ \\
\hline $3 j$ & $>100$ & $>100$ & $>100$ & $>100$ & $>100$ & $>100$ \\
\hline Brivudin & $>250$ & 0.05 & 199 & 10 & 10 & $>250$ \\
\hline Ribavirin & $>250$ & 2 & 2 & 2 & 10 & $>250$ \\
\hline Cidofovir & $>250$ & 0.7 & 1.1 & 3.5 & $>250$ & $>250$ \\
\hline Ganciclovir & $>100$ & 0.03 & 0.03 & 0.1 & $>100$ & $>100$ \\
\hline
\end{tabular}

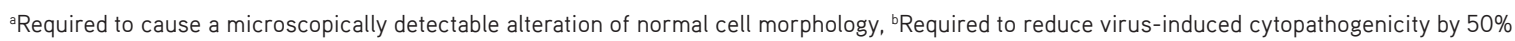


Table 5. Antiviral activity and cytotoxicity of the compounds 3a-j in Vero cell cultures

\begin{tabular}{|c|c|c|c|c|c|c|}
\hline \multirow{2}{*}{ Compound } & \multirow{2}{*}{$\begin{array}{l}M^{M C C^{a}} \\
(\mu \mathrm{M})\end{array}$} & \multicolumn{5}{|c|}{$\mathrm{EC}_{50}{ }^{\mathrm{b}}(\mu \mathrm{M})$} \\
\hline & & Parainfluenza- 3 virus & Reovirus-1 & Sindbis virus & Coxsackie virus B4 & Punta Toro virus \\
\hline $3 a$ & $>100$ & $>100$ & $>100$ & $>100$ & $>100$ & $>100$ \\
\hline $3 b$ & 100 & $>20$ & $>20$ & $>20$ & $>20$ & $>20$ \\
\hline $3 c$ & 20 & $>4$ & $>4$ & $>4$ & $>4$ & $>4$ \\
\hline $3 d$ & $>100$ & $>100$ & $>100$ & $>100$ & $>100$ & $>100$ \\
\hline $3 e$ & 20 & $>4$ & $>4$ & $>4$ & $>4$ & $>4$ \\
\hline $3 f$ & $>100$ & $>100$ & $>100$ & $>100$ & $>100$ & $>100$ \\
\hline $3 g$ & 40 & $>8$ & $>8$ & $>8$ & $>৪$ & $>8$ \\
\hline $3 \mathrm{~h}$ & 100 & $>20$ & $>20$ & $>20$ & $>20$ & $>20$ \\
\hline $3 i$ & $\geq 20$ & $>20$ & $>20$ & $>20$ & $>20$ & $>20$ \\
\hline $3 j$ & 100 & $>20$ & $>20$ & $>20$ & $>20$ & $>20$ \\
\hline DS-5000 ( $(\mu \mathrm{M})$ & $>100$ & $>100$ & $>100$ & 15 & $>100$ & 20 \\
\hline (S)-DHPA ( $\mu$ M) & $>250$ & $>250$ & $>250$ & $>250$ & $>250$ & $>250$ \\
\hline Ribavirin $(\mu \mathrm{M})$ & $>250$ & 29 & 146 & $>250$ & $>250$ & 112 \\
\hline
\end{tabular}

aRequired to cause a microscopically detectable alteration of normal cell morphology, ${ }^{\mathrm{b}}$ Required to reduce virus-induced cytopathogenicity by $50 \%$

Conflict of Interest: No conflict of interest was declared by the authors.

\section{REFERENCES}

1. Krasnov VP, Vigorov AY, Musiyak VV, Nizova IA, Gruzdev DA, Matveeva TV, Levit GL, Kravchenko MA, Skornyakov SN, Bekker OB, Danilenko VN, Charushin VN. Synthesis and antimycobacterial activity of $\mathrm{N}$-(2aminopurin-6-yl) and $\mathrm{N}$-(purin-6-yl) amino acids and dipeptides, Bioorg Med Chem Lett. 2016;26:2645-2648.

2. Bhowruth V, Dover LG, Besra GS. Tuberculosis chemotherapy: recent developments and future perspectives. Prog Med Chem. 2007;45:169203.

3. WHO Global Tuberculosis Report, 2015. http://apps.who.int/iris/ bitstream/10665/191102/1/9789241565059_eng.pdf (accessed August, 2016).

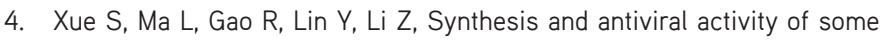
novel indole-2-carboxylate derivatives. Acta Pharm Sin B. 2014;4:313-321.

5. El-Sabbagh OI, Baraka MM, Ibrahim SM, Pannecouque C, Andrei G, Snoeck R, Balzarini J, Rashad AA. Synthesis and antiviral activity of new pyrazole and thiazole derivatives. Eur J Med Chem. 2009;44:3746-3753.

6. Gudmundsson KS, Johns BA, Allen SH. Pyrazolopyridines with potent activity against herpesviruses: effects of $\mathrm{C} 5$ substituents on antiviral activity. Bioorg Med Chem Lett. 2008;18:1157-1161.

7. Romanutti C, Castilla V, Coto CE, Wachsman MB. Antiviral effect of a synthetic brassinosteroid on the replication of vesicular stomatitis virus in Vero cells, Int J Antimicrob Agents. 2007;29:311-316.

8. Andries K, Moermans M, Grevers T, Willebrords R, Sommen C, Lacrampe J, Janssens F, Wyde PR. Substituted benzimidazoles with nanomolar activity against respiratory syncytial virüs. Antiviral Res. 2003;60:209219.
9. Wyde PR, Chetty SN, Timmerman P, Gilbert BE, Andries K. Short duration aerosols of JNJ 2408068 (R170591) administered prophylactically or therapeutically protect cotton rats from experimental respiratory syncytial virus infection. Antiviral Res. 2003;60:221-231.

10. Juspin T, Laget M, Terme T, Azas N, Vanelle P. TDAE-assisted synthesis of new imidazo[2,1-b]thiazole derivatives as anti-infectious agents, Eur J Med Chem. 2010;45:840-845.

11. Andreani A, Granaiola M, Leoni A, Locatelli A, Morigi R, Rambaldi M. Synthesis and antitubercular activity of imidazo[2,1-b]thiazoles. Eur $J$ Med Chem. 2001;36:743-746.

12. Barradas JS, Errea MI, D'Accorso NB, Sepúlveda CS, Damonte EB. Imidazo [2,1-b]thiazole carbohydrate derivatives: Synthesis and antiviral activity against Junin virus, agent of Argentine hemorrhagic fever. Eur J Med Chem. 2011;46:259-264.

13. Ding $H$, Chen $Z$, Zhang $C$, Xin $T$, Wang $Y$, Song $H$, Jiang $Y$, Chen $Y, X u$ $\mathrm{Y}$, Tan $\mathrm{C}$. Synthesis and cytotoxic activity of some novel $\mathrm{N}$-pyridinyl2-(6-phenylimidazo[2,1-b]thiazol-3-yl)acetamide derivatives, Molecules. 2012;17:4703-4716.

14. Abdelal AM, Gineinah MM, Tayel MM, Tantawy A. Imidazo[2,1-b]thiazoles: Synthesis and antiinflammatory activity of some new 3,5-disubstituted 6-phenylimidazo[2,1-b]thiazoles. Sci Pharm. 1993;61:21.

15. Andreani A, Rambaldi M, Mascellani G, Rugarli Pi. Synthesis and diuretic activity of imidazo[2,1-b]thiazole acetohydrazones. Eur J Med Chem. 1987;22:19-22.

16. Küçükgüzel ŞG, Rollas S, Erdeniz H, Kiraz M. Synthesis, characterization and antimicrobial evaluation of ethyl 2-arylhydrazono-3-oxobutyrates. Eur J Med Chem. 1999;34:153-160.

17. Eldehna WM, Fares M, Abdel-Aziz MM, Abdel-Aziz HA, Design, synthesis and antitubercular activity of certain nicotinic acid hydrazides. Molecules. 2015;20:8800-8815. 
18. Narang R, Narasimhan B, Sharma S, Sriram D, Yogeeswari P, De Clercq E, Pannecouque C, Balzarini J. Synthesis, antimycobacterial, antiviral, antimicrobial activities, and QSAR studies of nicotinic acid benzylidene hydrazide derivatives. Med Chem Res. 2012;21:1557-1576.

19. Sundaree S, Vaddula BR, Tantak MP, Khandagale SB, Shi C, Shah K, Kumar D. Synthesis and anticancer activity study of indolyl hydrazidehydrazones. Med Chem Res. 2016;25:941-950.

20. Navidpour L, Shafaroodi H, Saeedi-Motahar G, Shafiee A. Synthesis, antiinflammatory and analgesic activities of arylidene-2-(3-chloroanilino) nicotinic acid hydrazides. Med Chem Res. 2014;23:2793-2802.

21. Ulusoy Güzeldemirci N, Şatana D, Küçükbasmacı Ö. Synthesis, characterization, and antimicrobial evaluation of some new hydrazinecarbothioamide, 1,2,4-triazole and 1,3,4-thiadiazole derivatives. J Enzyme Inhib Med Chem. 2013;28:968-973.

22. Ulusoy Güzeldemirci N, Küçükbasmacı Ö. Synthesis and antimicrobial activity evaluation of new 1,2,4-triazoles and 1,3,4-thiadiazoles bearing imidazo[2,1-b]thiazole moiety. Eur J Med Chem. 2010;45:63-68.

23. Gürsoy E, Güzeldemirci NU. Synthesis and primary cytotoxicity evaluation of new imidazo[2,1-b]thiazole derivatives. Eur J Med Chem. 2007; 42:320-326.

24. Ulusoy N, Kiraz M, Küçükbasmacı Ö. New 6-(4-bromophenyl)imidazo[2,1-b]thiazole derivatives: Synthesis and antimicrobial activity. Monatsh Chem. 2002;133:1305-1315.

25. Ulusoy N. Synthesis and antituberculosis activity of cycloalkylidenehydrazide and 4-aza-1-thiaspiro[4.5]decan-3-one derivatives of imidazo[2,1-b]thiazole. Arzneim-Forsch/Drug Res. 2002;52:565-571.
26. Ulusoy N, Çapan G, Ötük G, Kiraz M. Synthesis and antimicrobial activity of new 6-phenylimidazo[2,1-b]thiazole derivatives. Boll Chim Farmaceutico. 2000;139:167-172.

27. Çapan G, Ulusoy N, Ergenç N, Kiraz M. New 6-phenylimidazo[2,1-b] thiazole derivatives: Synthesis and antifungal activity. Monatsh Chem. 1999;130:1399-1407.

28. Karaman B, Ulusoy Güzeldemirci N. Synthesis and biological evaluation of new imidazo[2,1-b]thiazole derivatives as anticancer agents. Med Chem Res. 2016;25:2471-2484.

29. Clinical and Laboratory Standards Institute. Performance standards for antimicrobial testing, (15 th ed). Informational supplement. M100-S15. Wayne, PA; Clinical and Laboratory Standards Institute; 2005.

30. Collins LA, Franzblau SG. Microplate alamar blue assay versus BACTEC 460 system for high-throughput screening of compounds against Mycobacterium tuberculosis and Mycobacterium avium. Antimicrob Agents Chemother. 1997;41:1004-1009.

31. Inderleid CB. Antibiotics in Laboratory Medicine. In: Lorian V, ed. (3 ${ }^{\text {rd }}$ ed). Williams \& Wilkins; Baltimore; 1991:134.

32. Krečmerová M, Holý A, Pohl R, Masojidková M, Andrei G, Naesens L, Neyts J, Balzarini J, De Clercq E, Snoeck R. Ester prodrugs of cyclic 1-(S)-[3hydroxy-2-(phosphonomethoxy)propyl]-5-azacytosine: synthesis and antiviral activity. J Med Chem. 2007;50:5765-5772.

33. Harraga S, Nicod L, Drouhin JP, Xicluna A, Panouse JJ, Seilles E, Robert JF. Imidazo[2,1-b]thiazole derivatives. XI. Modulation of the CD2-receptor of human $\mathrm{T}$ trypsinized lymphocytes by several imidazo[2,1-b]thiazoles. Eur J Med Chem. 1994;29:309-315. 